\title{
From Nails to Rails: A Report in the Practical Application of Theoretical Museology
}

De los clavos a los rieles: un informe sobre la aplicación práctica de la museología teórica

\section{Victoria Miller}

\section{CpenEdition}

\section{Journals}

Electronic version

URL: https://journals.openedition.org/iss/3302

DOI: $10.4000 /$ iss. 3302

ISSN: 2306-4161

\section{Publisher}

ICOM - International Council of Museums

\section{Printed version}

Date of publication: 18 December 2021

Number of pages: $107-117$

ISBN: 978-92-9012-446-7

ISSN: 2309-1290

\section{Electronic reference}

Victoria Miller, "From Nails to Rails: A Report in the Practical Application of Theoretical Museology", ICOFOM Study Series [Online], 49-1 | 2021, Online since 18 December 2021, connection on 08 January 2022. URL: http://journals.openedition.org/iss/3302 ; DOI: https://doi.org/10.4000/iss.3302 


\title{
From Nails to Rails: A Report in the Practical Application of Theoretical Museology
}

\author{
Victoria Miller \\ Steelworks Center of the West - Pueblo, \\ Colorado, USA
}

ABSTRACT

Theoretical museology is the study of museums, including explorations of their history, role in society, and the activities they engage in for the benefit of the communities that they serve which include curating, public programming, education and preservation.

This paper will examine the theoretical foundations and a practical application of museology at the Steelworks Center of the West in Pueblo, Colorado (USA). The aim is to stimulate critical thinking on the transfer and cross-cultural application of standard, professional museum models and methods. It will also examine how the Steelworks Center provides for a study of museology within the environment, particularly regarding the ways in which people learn. These will include the role of museum education as an alternative to the tradi- 
tional methods of study, and also, museum education as a trainer for non-conformist thinking.

Key words: museology, communities, programming, critical thinking, application, methods

RESUMÉN

\section{De los clavos a los rieles: un informe sobre la aplicación práctica de la museología teórica}

La museología teórica es el estudio de museos incluyendo exploraciones de su historia, papel en la sociedad, las actividades que realizan en beneficio de sus comunidades, a las que sirven que incluyen curación, programación pública, educación y preservación.

Este trabajo examinará las bases teóricas y una aplicación práctica de la museología en el Steelworks Center of the West en Pueblo, Colorado (EE.UU.). El objetivo es estimular el pensamiento crítico sobre la transferencia y aplicación intercultural de modelos y métodos museísticos estándar y profesionales. También examinará cómo el Steelworks Center prevé un estudio de museología dentro del medio ambiente, particularmente en cuanto a las formas en que las personas aprenden. Estos incluirán el papel de la educación museística como alternativa a los métodos tradicionales de estudio, y en segundo lugar, la educación museística como formador del pensamiento inconformista.

Palabras clave: museología, comunidades, programación, pensamiento crítico, aplicación, métodos.

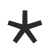

Museums are extraordinary places where visitors have an incredible range of educational experiences. For some people, their first exposure to a painting, piece of sculpture or drawing may be in one of the hundreds of art museums in the world. For others, a trip to the museum may be the first time a visitor sees a living history reenactment or demonstration. Yet for others, their first experience at a museum may be through participation in one of the many educational or outreach classes that many museums offer throughout the year.

This paper will report on the practical application of theoretical museological methods used at the Steelworks Center of the West, (where I am employed), and how it provides for a study of museology within the environment, particularly regarding the ways in which people learn. These will include the role of 
museum education as an alternative to the traditional methods of study, and also, museum education as a trainer for non-conformist thinking.

\section{Background to the Colorado Fuel and Iron Company}

Southern Colorado has a strong history of ties to generations of indigenous peoples in the United States, mainly the Ute, Arapahoe, Pawnee, Comanche, Apache, and Kiowa. Pueblo, Colorado lies at the confluence of the Arkansas River and Fountain Creek in southern Colorado. The city traces its roots of official incorporation to 1870 . The community was an important trading and agricultural center in southern Colorado for two decades prior to incorporation. There are currently two other museums within the city that interpret this early history in their programming and exhibitions: Pueblo Heritage Museum and El Pueblo History Museum, a regional museum of the Colorado Historical Society.

What became the Colorado Fuel and Iron Company (CF\&I) traces its roots to just two years after city development and operated as the first fully integrated steel mill west of the Mississippi River (Scamehorn, 1976). It took thousands of employees to operate such a massive company, and, for many years, it served as the state's largest private employer. Within southern Colorado and northern New Mexico's coal fields, a necessary element to the steelmaking process, were thousands of native peoples, along with newly arrived immigrant groups from Mexico and Europe. Although not entirely indigenous, generations of these people made their living as farmers and ranchers, and as miners for smaller mining agencies or independent mines. As the company grew more powerful and became the preeminent industry in the region, it acquired many of these smaller mines and purchased land and water rights from former farms and ranches.

As technology evolved, the Colorado steel plant moved from using raw materials to produce steel and began relying on recycling scrap steel to make new products. The mines were abandoned and sold to support the plant's operations in a troubled economy. The company continued to experience economic hardship and the CF\&I Steel Corporation filed for bankruptcy in 1990. Oregon Steel Mills purchased the assets of CF\&I in 1992 and continued to operate it into the new millennium. In 2006, the Russian steel giant EVRAZ purchased the property and continues to operate the Pueblo steel site today (Miller \& Schreck, 2018).

\section{Founding of the Steelworks Museum and All Its Functions}

Founded in the summer of 2000, the Steelworks Center of the West has the primary mission to provide permanent care for the archives, artifacts and historic office complex created by CF\&I. The organization collects, preserves, interprets, and exhibits the collections of the steel and mining industry, the surrounding Bessemer neighborhood, and the cultural contributions of those 
who worked in the industry. In addition to its main mission, the organization is dedicated to the preservation of the legacy and contributions the company made to the City of Pueblo, the State of Colorado, and the United States, and to continually broaden access to this rich heritage for researchers and visitors to the project site(s) (Steelworks Center of the West, 2020).

After a successful capital campaign raised $\$ 1.75$ million, the Steelworks Center purchased the 5.7 acres of land directly to the west of the steel mill and four buildings totaling nearly 100,000 square feet with the intention of preserving Southern Colorado's steel and mining heritage. Following the purchase of the buildings, Oregon Steel Mills, at the time owners of the steel mill, formally donated the archival contents created by their predecessor to the Steelworks Center. The donation came with a clear understanding of the importance of the collection in the history of the American West and in the history of our nation.

Following the purchase and stabilization of the building, processing of the collection to make it accessible to the public immediately began. The significance of this collection was reinforced with the opening of the Steelworks Museum in January 2007. Here in our public area, guests can view exhibits comprising contents of the archive and artifacts, watch films from the collection, and participate in many hands-on learning experiences.

This is the first phase of what will be a much larger museum complex in future years. The museum includes visual exhibits based on photographs, 3-dimensional artifacts and text on the following: timeline of company history, broken down into significant time periods, interpretation of the medical examining rooms where employees received physicals, strength, hearing and other occupational-related tests, and an x-ray room. The main gallery is dedicated to the pivotal period in CF\&I's history (1915-1936) and examines the administrative and social changes the company made following the mining related Colorado Coal Field strike of 1914. Multimedia exhibits examine life in the mining camps, the history of steelmaking, labor relations, diversity in the workplace, and other topics while making extensive use of materials from the archive collection. A smaller rotating gallery space changes annually and is based on themes relevant to materials available from the collection. Recent exhibits include: 'The immigrant surge to the company's payroll at the turn of the $20^{\text {th }}$ century'; 'The company's contribution to America's victory during WWI', and 'The women involved in the history of the company'. The current exhibit focuses on CF\&I's relationship with water as a necessary element in the steelmaking process.

Since its opening 14 years ago, the museum has served as a popular destination for the general public, scholars, life-long learners and, particularly, school groups. Education staff provide a wide range of hands-on programs for young people in grades kindergarten-secondary school. A small number of undergraduate and graduate students also utilize the museum as a hands-on learning lab and classroom. Using materials exclusively from the archive collection 
created by CF\&I, the museum serves approximately 5,000 onsite visitors and thousands more online annually.

CF\&I created one the most comprehensive, publicly accessible corporate collections in America. At a little over 6,000 cubic feet with materials dating from 1856-1993, it represents a major resource for researchers exploring America's industrial past. The archives document all aspects of CF\&I's long history and are unusual in their completeness. Many corporate archives have been heavily purged before entering into the public sphere, but the CF\&I archives were simply abandoned intact when the company went out of business. Researchers of all levels are able to trace the complete life cycle of an important American corporation from its inception to its demise. The collection comprises a wide variety of media including: 100,000 photographs, 30,000 maps, 15,000 drawings, 8- and 16-millimeter film, architectural schematics and blueprints, and millions of paper documents. These include company produced newspapers, personnel files, company memoranda, sales reports and catalogs, financial statements, mining documentation and more. The collection is a microcosm of American industry; it illustrates the birth, growth and decline of a vertically integrated company. Researchers use the collection to tell the stories of the growth of industry in the West, the history of technology, western immigration, labor history, the development of industrial medicine, family history and countless other topics. Much of the documentary heritage of the Eastern United States steel mills has been lost, making the documentary sources that survive all the more important.

The archives are a microcosm of American industry, and their depth, range and completeness represent unique opportunities for researchers from numerous disciplines. Some of the specific products to come out of research projects include masters theses and $\mathrm{PhD}$ dissertations, scholarly journal articles, books, documentary films shown in public forums, and elementary and secondary school research papers. For our younger students in particular, the benefits of studying the contents of the CF\&I collection are twofold. First, it gives them the opportunity to study historic material that was not necessarily available publicly during the life of the company: because of the competitive nature of CF\&I's business, the company kept "trade secrets" and limited the number of materials released to the public about its operations. Now that the company is no longer in existence, those records are (mainly) open for inspection and study.

Second, studying the contents of the archive gives students the opportunity to examine primary source materials created at a particular moment in time. They are able to smell the unforgettable odor of aging paper, see (and need to translate in some cases) the handwriting in some of our older documents from the late $19^{\text {th }}$ century, and visually comprehend the enormous breadth of some of the financial ledgers, an experience that they do not necessarily receive from reading secondary sources on the same topic. 


\section{Development of Educational Theory}

Though one of the primary functions of a museum today is to educate its public, this has not always been the case. History is able to trace the earliest museums back to the Ancient world in which the Mouseion was a temple dedicated to serving as a research center only for academics and scholars of the period. Though the temple contained objects, mainly those valued for their historic, religious, or aesthetic importance, it was primarily a university and philosophical academy (Alexander, 1979).

Through the years, the idea of a museum shifted from that of an academic seat of learning to an exhibition setting where objects from near and far could be displayed, serving as a showcase of conquests (Alexander, 1979). By the time of the Enlightenment, societal views had changed from a museum being a showcase of wealth to a site whose collection "would help educate humankind and abet its steady progress toward perfection" (Alexander, 1979, p. 8). It was with this new quest that the private collections of the elite became public collections for the mass population. With the stance of public ownership, the public's desire to learn and understand its collection became more widespread.

It was at the turn of the $20^{\text {th }}$ century, a time of political upheavals reflected in progressive ideas towards education, that the most significant changes relating to museum education were made. Teachers and educational theorists John Dewey (1859-1952) and John Cotton Dana (1856-1929), both of whose philosophies epitomized the progressive movement at the turn of the century, called for changes within the American education system to include more museum experiences. "A good museum attracts, entertains, arouses curiosity, leads to questioning and thus promotes learning," Dana writes (1909, as cited in Edson \& Dean, 2003, p. 185). He continues by emphasizing, "It is an educational institution that is set up and kept in motion - that it may help the members of the community to become happier, wiser, and more effective" (Dana, 1909, as cited in Edson \& Dean, 2003, p. 185). Because both Dewey and Dana advocated the importance of education improving society, the primacy of experience, the use of objects for learning, and the need for a rich learning environment, museums saw an opportunity to expand their missions (Hein, 2004). Furthermore, Talboys (2000) writes, "By recognizing education as their reason for being, museums not only returned to the purpose for which they were created, but also firmly established themselves in a role that is essential to the future of society" (p. 8). The viewpoint that one of a museum's main reasons for existence is to educate continues to this day.

So, what is it about museum education that is different from classroom education? Although both settings allow for numerous educational opportunities, it is within the confines of a museum that allows us to communicate messages, tell stories, and understand the world around us through distinct means. This is particularly important to reach the student who may otherwise not feel comfortable to communicate or participate under standard classroom cir- 
cumstances. Based on original objects and making use of sensory perception, museum education is supported by sound scientific or historical research, yet in presentation is informal, voluntary, and is often enjoyable and entertaining to the visitor. Moreover, it may seek other ways of satisfying people's newly aroused curiosities.

One effective example of this at the Steelworks Center is the exhibit relating to nail manufacturing. When guests approach the exhibit's 1930s era nail-making machine, they receive a near full sensory experience. At the exhibit station, they smell the grease used to lubricate the machine, turn the crank handle to experience how difficult it was to rotate the flywheel and subsequent gears, levers and other components to the machine. Pushing a button near the machine engages a short, 15-second recording of the sound of the machine when it was working in the steel mill. A curved, oversized 1920s photograph of the room in which the nail machine was once housed before transfer to the museum simulates the experience of standing next to the machine in situ. Engaging four of the five senses at this exhibit gives visitors more of a sense of working in the mill in the late 1920s and early 1930s than just reading a text panel.

The education gained from this exhibit is not formal; there are no exams or questions to test visitors' knowledge retention as they move to other areas of the museum. There is, however, an element to inspire their further quest for knowledge following the visit: "Are nails manufactured on a machine similar to this one today?" "How many nails per minute could a machine produce?" "What was the size of CF\&I's largest or smallest nail?" The attitudes of purposeful education and the competition of other cultural and leisure time activities led to yet another philosophical change in museums during the $20^{\text {th }}$ century and continues today. It is perhaps within the past century that we have seen the most significant changes in the equal access of museums.

Museum professionals today understand the competition for the public's attention and time. Positive outreach experiences, well-trained and professional staff, and creative marketing enhance the reputation of the museum as a place the public wants to experience (Edson \& Dean, 2003, p. 9). Today's museum leaders understand that their very existence is for the public. As the authors point out, the concept of public service is on the importance of the visitor, and exhibitions and programs are now specifically designed to fit their interests (Edson \& Dean, p. 6). Such examples include programs aimed at all audiences from the youngest of children to the elderly. Family days, lectures, fundraisers, and tours, as well as the way in which the collection itself is exhibited, appeal to both established and potential audiences and their interests. Furthermore, the museum professional constantly looks for new audiences that might benefit from the institution.

At the Steelworks Center of the West, our education programming does just this. In addition to our exhibits, throughout the year, we offer programs that cater to all audiences including: adult lectures in informal situations such as 
on guided tours through the museum and in our formal lecture "Steelworks Speaker" series. For younger visitors, we offer hands-on learning experiences to those in formal (within a structured school activity) and informal (school trips, youth groups and homeschool groups) learning environments. For families, we offer a monthly "Family Science Saturday" program, a hands-on learning experience in which parent and child together can participate in learning about the wonders of science and how those themes mesh with CF\&I history. During our Steel'ebration fundraising effort, we offer bus tours through the EVRAZ steel mill with a tour guide on the bus describing the steelmaking process and explaining the different buildings and sites that the guest can see up close and personal. Other parts of the day include a heritage festival on the grounds surrounding the museum building including folkloric dancing, music, and food. For the more technically-minded, or those unable to visit the museum in person, we offer educational photographs and interpretive text daily on our social media outlets. The ethnic and cultural composition of audiences for our exhibits and programming reflect the composition of the Pueblo community, which in 2019 was estimated to include $43.2 \%$ of residents identifying as Latino, $51.7 \%$ identifying as Caucasian non-Latino, and 9.8\% identifying as other races (US Census Bureau, 2020).

Audiences for our educational programs vary depending on which teaching method is used. The main exhibitions and daily social media postings, made of primarily photographs, text, 3-dimensional artifacts and ephemera from the archive collection, are designed for a general audience, although young students are able to understand and make correlations to the exhibits as well. Our hands-on programming is specifically designed for younger students depending on their age group. Archives staff are available for those researching in the collection who might need assistance in interpreting historical materials. Due to the fact that museum teaching is traditionally informal, at this time, there has been no formal study conducted on the impact our lessons and programs have had on our audiences.

What is in store for the museum of the future? As Moore (1997) points out,

Museums have a key task to play in providing an understanding of identity and sense of belonging to a place or community. In the face of immense and often painful cultural change in many countries, museums can provide a valuable sense of connection with the past and present, and serve as a springboard for the future. (p.18)

Students learn in a variety of ways, and not all students can benefit from the traditional transmission-based "teacher knows all and deposits in the student's brain" philosophy. With a museum's method of experiential learning, students have the opportunity and freedom to learn at their own pace, discover, question, 
and see for themselves aspects that they might not have had the opportunity to through the transmission teaching approach. What's more, with such an experiential mode of learning, students feel that they are part of the learning process, which allows them to have the sense that they are part of the greater whole.

Another advantage of museum learning is that museums can offer real objectstangible examples of objects, ideas, history, and processes, whereas classroom learning is limited to books, lectures, media, and simple hands-on experiences. Indeed, learning about a particular subject may be impossible in a classroom setting because of budgetary constraints, lack of access to resources or lack of knowledge or training,. Therefore, students must travel outside to a museum to make the most of the planned lesson. It is during this trip that "unexpected things happen...surprise, challenge, emotion, all these elements keep students engaged. When children sit passively in a classroom, they tend to lose interest" (Willis, 1997, p. 2). One such method of this type of pedagogy often used by museums is through object-based learning. Developed by Swiss educator Johann Heinrich Pestalozzi (1746-1827), this method of learning strives to develop students' skills by incorporating sensory perception, thinking, and language. As Smith (2013) points out, Pestalozzi held that children should learn through activity or things rather than the previously accepted pedagogy of learning through words, as was the custom of the late $19^{\text {th }}$ and early $20^{\text {th }}$ century in America. With this freedom, children could then draw their own conclusions.

Thus, object-based learning combines the inherent information provided by an object with the viewer's experiences, feelings, and thoughts to provide a dynamic and unique learning opportunity that is accessible to a broad range of students. Furthermore, this method focuses on the senses in exploring objects; discusses meaning, associating objects with others; places objects in other contexts; and links objects to other subject areas. By utilizing object-based learning, teachers are able to identify a child's learning style and can then direct individual attention based on this research to bring learning to life back in the classroom.

There is a small committee within the Steelworks Center of the West comprising museum staff, professional teachers (elementary and secondary) and community members who work together to develop educational curricula. Lessons are researched, confirming that they meet Colorado Education Standards, supplies are purchased, and finally lessons are tested on a small focus group of students. Commentary and feedback is collected from the focus group, and the lesson is added to the regular rotation of offerings at the museum serving a larger audience. To ensure the lessons are utilized, either in the classroom if the lesson is distributed to the teacher or in the museum if the class visit for an in-house learning experience, a short email is written to the teacher explaining the purpose of the lesson and how it meets Colorado education standards. This information is imperative to justify the disruption of the students' normal daily routine and engagement in the lesson(s). 
One example of a successful incorporation of object-based learning occurs within the Steelworks Center of the West's program, "History Detective," developed by the education department at the Steelworks Museum. In this "museum in a box," several tangible historical items are available to teachers for a two-week-long loan period or to use as the students visit the museum. The kit includes objects that the $4^{\text {th }}$-grade student of the year 2021 may not be familiar with, but were commonly used by families long ago. Some items include a buttonhook, boot hooks, flower frog, wire draw, soap saver, and a curry comb, among others. Age-appropriate worksheets accompany the kit for group work activities. No labels are provided for the students identifying the objects or their historical context. Guided questions within the provided lesson plan include utilizing all the senses to examine each object, exploring materials used to create the object, assessing the condition of the object, etc., and allow the student to make careful insights and connections based on their preliminary research of what the object might be and in what context it was originally used. Incorporating Dewey's theory that knowledge builds upon itself, with object-based learning, in a museum setting, the museum educator inspires a visitor to build on previous knowledge and to discover new information about an object or its context (Hein, 2004). After discussion and revelation of the purpose and significance of the kit's objects, the teacher is then encouraged and assisted by Steelworks Museum staff to develop cross-curriculum in other subject areas relating to science, math, and art.

Other authors point out that museum education can play another role, that of trainer for non-conformist thinking. Panzer (1976) discusses the museum educator's role not just as a lecturer, but as a conductor in allowing people to discover their own intellectual and sensory responses. With this revolutionary new way of envisioning the role of museum education, she goes on to say that a museum must be everything that a school is not: "No lectures, no memorized information, no demand for right answers, no tests. The effective docent encourages the viewers to become the directors of the content of the encounter, which is, after all, uniquely their own" (Panzer, 1976, p. 2).

Furthermore, Mann (1997) argues that some museums must have the ultimate function for posing questions, not just for supporting curriculum content. In his article, he refers to the INVESTIGATE! Science Center in Boston, whose mission is to have visitors "encounter experiences, rather than exhibits or programs" (Mann, 1997, p. 6). This gives the visitor a chance to live the life of a scientist, by predicting and testing hypotheses, not just learn about it through lecture or readings. This museum's mission is "to avoid subjects... [and to] teach principles or facts, but to offer experiences in thinking and problem solving" (Mann, 1997, p. 6).

In conclusion, effective museum education allows students to not only view the material in front of them, but also interact with that material through asking questions, handling the objects, and exploring the processes that lead to a richer understanding of the world around them (Hein, 2004). It is perhaps Alexander 
(1979) who summed up museum education best by stating, "It is voluntary and dependent only on the interest of the viewer and is often enjoyable and entertaining. It may furnish one with strong motivation to read further, to visit other places, and seek other ways of satisfying one's curiosities" (1979, p. 196). Museums are wonderful places of learning not only about historical objects but also, through studying these objects, about ourselves.

\section{References}

Alexander, E.P. (1979). Museums in motion: An introduction to the history and functions of museums. American Association for State and Local History.

Edson, G., \& Dean, D. (2003). The handbook for museums. Routledge. Hein, G.E. (2004). John Dewey and museum education. Curator, 47(4), 413-426. https://dx.doi.org/10.1111/j.2151-6952.2004.tb00136.x

Mann, L. (1997, Winter). Extending the curriculum through museums. Curriculum Update, 6-8. www.ascd.org/publications/curriculum-update/ winter1997/Field-Studies.aspx

Miller, V., \& Schreck, C. (2018). The Colorado Fuel and Iron Company. Images of America series. Arcadia Press.

Panzer, N. (1976). The docent as catalyst. Smithsonian Institution Archives, Record Unit 456, Office of Educational Programs, Program Records. National Museum of American Art.

Scamehorn, H.L. (1976). Pioneer steelmaker in the West: The Colorado Fuel and Iron Company 1872-1903. University of Colorado Press.

Smith, M.K. (1996, 2008). Johann Heinrich Pestalozzi: Pedagogy, education and social justice. infed.org: education, community-building, and change. http:// www.infed.org/thinkers/et-pest.htm

Steelworks Center of the West (n.d.). Education. https://www.steelworks.us/ education/

Talboys, G.K. (2000). Museum educator's handbook. Gower.

Willis, S. (1997, Winter). Field studies: Learning thrives beyond the classroom. Curriculum Update, 1-2. wwwl.ascd.org/publications/curriculum-update/ winter1997/Field-Studies.aspx

US Census Bureau. (2020). Quickfacts: Pueblo County, Colorado. US Department of Commerce. https://www.census.gov/quickfacts/fact/table/ pueblocountycolorado/RHI125219 